Saudi Journal of Business and Management Studies Abbreviated Key Title: Saudi J Bus Manag Stud ISSN 2415-6663 (Print) |ISSN 2415-6671 (Online) Scholars Middle East Publishers, Dubai, United Arab Emirates Journal homepage: http://scholarsmepub.com/sjbms/

Original Research Article

\title{
Market Growth Strategies and Performance of Small and Medium Scale Enterprises in Benue State, Nigeria
}

\author{
Asenge, Emmanuel Lubem ${ }^{1 *}$, Asue, Timothy Terkimbir ${ }^{2}$ \\ ${ }^{1}$ Department of Business Management, Benue State University, Makurdi-Nigeria \\ ${ }^{2}$ Department of Business Administration, Federal University of Agriculture, Makurdi- Nigeria
}

DOI: $10.36348 /$ sjbms.2020.v05i01.001 | Received: 27.12.2019| Accepted: 04.01.2020 | Published: 11.01.2020

*Corresponding author: Asenge, Emmanuel Lubem

\section{Abstract}

In all economies Small and Medium Scale Enterprises (SMEs) constitute the vast majority of business establishments thereby contributing to employment generation, poverty reduction, Gross Domestic Product (GDP) and household income. Stiff competition requires SMEs to adopt different strategies to improve performance. This study examines the effect of market growth strategies on the performance of small and medium scale enterprises in Benue State, Nigeria. The study specifically examined the effect of product development strategy, market penetration strategy and quality customer service strategy on the performance of small and medium scale enterprises in Benue State, Nigeria. The study adopted a survey research design and questionnaire was used as the instrument for data collection. The population of the study includes 281 SMEs in Makurdi metropolis selected across different sectors including Retail/Wholesale, Services, Agribusiness and Manufacturing. Mean and standard deviation were used for data presentation and analysis while regression analysis was used for test of hypotheses. Findings of the study indicated that product development strategy and market penetration strategy have significant effect on the performance of small and medium scale enterprises in Benue State, Nigeria. The study also revealed that quality customer service strategy has significant effect on the performance of small and medium scale enterprises in Benue State, Nigeria. The study recommended amongst others that owners of SMEs in Benue State should always use strategies that will align market needs to be able to attract more customers and face competitors in the market.

Keywords: Growth Strategy, Performance, Product Development Strategy, Market Penetration Strategy, Quality Customer Service Strategy.

Copyright @ 2020: This is an open-access article distributed under the terms of the Creative Commons Attribution license which permits unrestricted use, distribution, and reproduction in any medium for non-commercial use (NonCommercial, or CC-BY-NC) provided the original author and source are credited.

\section{INTRODUCTION}

The contributions of Small and Medium Scale Enterprises (SMEs) to the economic growth and development of all economies have been globally acknowledged. Small and medium scale enterprises have played foremost roles in the growth of developed economies such as United States of America, China, Brazil, Saudi Arabia, amongst others [1]. Minniti [2] argued that in countries such as China, Brazil, Saudi Arabia and Malaysia different entrepreneurship programmes have been established to create an enabling environment for the performance of small and medium scale enterprises which enable them to contribute tremendously in reducing unemployment rate. It is estimated that SMEs contribute $56 \%$ of private sector employment and $36 \%$ of the Gross Domestic Product (GDP) worldwide [3]. In developing countries, SMEs are generally regarded as the driving force of economic growth, job creation and poverty reduction. They have been the means through which accelerated economic growth and rapid industrialization have been achieved $[4,5]$. Consequently, the performance of the SMEs sector directly affects the growth of every nation.

In Nigeria, the continual role played by SMEs in employment generation, economic growth, poverty reduction and income generation is irrefutable. Kadiri [6] averred that in both the formal and informal sectors SMEs employ over $60 \%$ of the labor force in Nigeria. 
Asenge, Emmanuel Lubem \& Asue, Timothy Terkimbir; Saudi J Bus Manag Stud, Jan., 2020; 5(1): 1-9

The growing concern about unemployment among the youths, especially of graduates of Universities and other tertiary institutions, and diminishing growth potentials in the economy have further drawn increased attention on the need to ensure the survival and growth of SMEs. There have been series of government interventions in Nigeria to boost the activities of SMEs through the establishment of agencies and programmes such as Small and Medium Enterprise Equity Investment Scheme (SMEEIS) established in 2001 and the Small and Medium Scale Enterprises Development Agency of Nigeria (SMEDAN) established in 2003. Other agencies include: the National Directorate of Employment (NDE), Skills Acquisition Centre and Industrial Development Centres [1]. SMEs need good strategies to improve their performance in the market and grow faster thereby increasing sales and profits.

A strategy is the direction and scope of organization over the long-term which enables it to achieve competitive advantage through configuration of resources within a changing environment to fulfill stakeholders' expectations [7]. A growth strategy might be described as a safest policy of growth-maximising gains and minimising risk and untoward consequences. Growth strategies adopted by businesses are either internal or external. Internal growth strategies are those in which a firm plans to grow on its own, without the support of others. On the other hand, external growth strategies are those in which a firm plans to grow by combining with others. In the fast expanding economies of today, adoption of growth strategies by business enterprises is a must for the survival, in the long-run; lest they should be swept away by environmental influences, especially competition, technology and governmental regulations. Common growth strategies adopted by SMEs include market penetration, market expansion, and product expansion and quality customer care strategies [4].

Starting and operating a business includes the possibility of success and failure. To face competition they must create strategies in order to grow beyond their scope. Most SMEs in Benue State use diverse growth strategies that enhance their viability in the market to gain competitive advantage. However, several factors limit the growth and performance of SMEs hence; limiting their ability to effectively contribute to the economic growth of Nigeria. This may be attributable to the failure of owners and managers of SMEs to come up with growth strategies that will enhance their business performance. The study will be imperative for entrepreneurs to understand the enormity of adopting appropriate growth strategies to enhance business growth, competitiveness and sustainability. Few studies are carried out locally to ascertain the magnitude of SMEs performance regarding adoption of growth strategies. To fill this gap, the study examines the effect of market growth strategies on the performance of small and medium scale enterprises in Benue State, Nigeria.

\section{OBJECTIVES OF THE STUDY}

The broad objective of this study is to examine the effect of market growth strategies on the performance of small and medium scale enterprises in Benue State, Nigeria. The specific objectives of the study include to:

- determine the effect of product development strategy on the performance of small and medium scale enterprises in Benue State, Nigeria;

- ascertain the effect of market penetration strategy on the performance of small and medium scale enterprises in Benue State, Nigeria; and

- $\quad$ Evaluate the effect of quality customer service strategy on the performance of small and medium scale enterprises in Benue State, Nigeria.

\section{RESEARCH HYPOTHESES}

The following null hypotheses have been formulated for this study:

$\mathrm{H}_{1}$ : Product development strategy has no significant effect on the performance of small and medium scale enterprises in Benue State, Nigeria

$\mathrm{HO}_{2}$ : Market penetration strategy has no significant effect on the performance of small and medium scale enterprises in Benue State, Nigeria

$\mathrm{HO}_{3}$ : Quality customer service strategy has no significant effect on the performance of small and medium scale enterprises in Benue State, Nigeria

\section{LITERATURE REVIEW \\ Concept of Market Growth Strategies}

Strategy, which is a fundamental management tool in any organization, is a multi-dimensional concept that various authors have defined in different ways. It is defined as the match between an organization's resources and skills and the environmental opportunities as well as the risks it faces and the purposes it wishes to accomplish [8]. Mintzberg and Quinn [9] also defined strategy as a pattern or a plan that integrates organization's major goals, policies and actions into a cohesive whole. A strategy is the pattern of plan that integrates an organization s goals, policies and action sequences into a cohesive whole [10]. Johnson and Scholes [7] view strategy as the direction and scope of an organization over the long-term, which achieves advantage for the organization through its configuration of resources within a changing environment, and fulfill stakeholder's expectations. The purpose of strategy is to provide directional cues to the organization that permit it to achieve its objectives while responding to the opportunities and threats in the environment [11]. Business growth strategy means an increase in the size 
or scale of operations of a firm usually accompanied by increase in its resources and output.

Growth strategy refers to a strategic plan formulated and implemented for expanding firm's performance [1]. Warugu [8] noted that growth strategies provide opportunities for the business enterprise to respond to the various challenges within its operating environment. According to Kiptugen[12], some of the growth strategies that a business enterprise may adopt are: understanding customer expectation, service, positioning market segmentation, setting measuring market standards, relationship marketing, human resource strategy and successful communication strategy. In this study, growth strategies refer to strategies adopted by small and medium scale enterprises that allow them to expand and employ more people to improve their performance. The more a firm grows, the more opportunities it has to create diverse products and services that can augment sustainability and benefit, not only the immediate people, but the institutional environment globally as well. For the purpose of this study, the following are among the market growth strategies that can be adopted by SMEs: product development strategy, market penetration strategy and quality customer service strategy.

Product development strategy refers to strategies the firm tries to grow by developing improved products for the present market. According to Watts, Cope and Hulme [13] the most suitable growth strategies for a small firm are those concerning product development and market development. Porter [14] shares the same view suggesting that high growth can best be achieved by identifying new markets for existing products or by developing new products or services for existing customers. In this way SMEs can evolve from having an established core activity into more complex businesses. Nooteboom [15] suggests that SMEs pursue product innovation strategies in emerging markets and marketing innovation strategies in mature niche markets. Yogo (2013) also suggests that product development strategy is a very effective strategy in mature markets with products in late life cycle stages.

Market penetration is a growth strategy, in which a firm tries to seek a higher volume of sales of present products by penetrating (or getting deeper), into existing markets. Market penetration strategy involves exploring new markets for company's products. For example, many companies have achieved remarkable growth by entering into foreign markets; pushing their products by changing size, packaging, and brand name [16]. Market penetration is a growth strategy based on increasing the firms existing share of products and markets. This strategy aims at increasing the sale of present product in the present market through aggressive promotion. The firm penetrates deeper into the market to capture a larger share of the market [13].
Mascarenas [17] claim that growth requires expanding what a firm is doing currently to a more potential customer. A business enterprise cannot serve the entire market with a particular product or service as customer needs and wants are diverse. It must identify segments of a market that it can serve most effectively [13].

Quality customer service strategy is the comparison made between the customer's expectation about a service and their perception of the way the service has been performed [18]. Customer satisfaction and loyalty is secured through high quality products and services. Providing value for money for consumer is essential for long term success [13]. Quality customer care strategies involve keeping existing customers and attracting new ones. When all these strategies are carefully adopted by SMEs there will be improvement in their performance [19]. Relationship marketing is the philosophy of doing business that focuses on keeping and improving current customers rather than on acquiring new ones. Businesses must see customers as their long term partners and need to make a commitment in maintaining the relationship through quality service and innovation, this is a good growth strategy notes.

\section{Concept of Performance of Small and Medium Scale Enterprises}

Performance refers to the resultant efforts by business enterprises in achieving stated objectives. This could be in form of sales growth, innovativeness, profitability and market share. SMEs performance can be measured in terms of sales volume, number of employees, or investment [20]. Performance of small and medium scale enterprises is the ability of such enterprises to contribute to job and wealth creation through enterprises start-up, survival and growth [21]. The performance of SMEs is a major driver and indices for the level of industrialization, modernization, employment creation, and income per capital, equitable distribution of income, and the welfare and quality of life enjoyed by the citizenry [22], because SMEs contribute to employment growth at a higher rate than larger firms [23]. Achieving a competitive advantage position and enhancing firm performance relative to its competitors are the main objectives that business organizations in particular should strive to attain [24]. Warugu [1] noted that these strategies provide opportunities for the business enterprise to respond to the various challenges within its operating environment.

Different measures of performance have been used by various scholars. Henezel [25] explained that to measure performance, SMEs must establish some standards and evaluate their strategies, values, practices by benchmarking with high performance SMEs. Yang [19] defined the dimensions of performance measurement as: growth, profit, size, liquidity, success/failure and others. In this study sales growth 
and innovativeness are used as measures of SMEs performance.

Sales growth refers to the amount a company derives from sales compared to a previous corresponding period of time in which the later sales exceed the former. It is usually given as a percentage [10]. Sales growth is considered positive for a company's survival and profitability. It is an important measure of performance [21]. Sales growth targets play a major role in the perceptions of business managers. Grant [13] argues that firms must use a wide variety of goals, including sales growth, to effectively reach their financial objectives. Factors that influence sales growth range from promotion to internal motivation and retaining of talented employees to the implicit opportunities for investments in new technologies and equipment in the production process.

Innovation is defined by Obasan [26] as the receipt and implementation of new ideas, processes, products or services. The practical evidence for a association between innovativeness and performance seems to be mixed. Innovation is regarded as an important measure of performance of small and medium scale enterprises [27]. According to Mian et al., [2] entrepreneurs with competitive innovation skills have a deep understanding of the SMEs which catapults their performance on the large extent. Dzisi et al. [18] explain that SMEs characteristics the root of their advancements level of innovative capacities to inside components, for example, self-inspiration, learning, knowledge, specialized capability and outer elements like client prerequisites and interest, data gave by suppliers of gear and materials, market open doors and rivalry.

\section{Relationship between Market Growth Strategies and Performance of SMEs}

The competitive environment for small and medium scale enterprises in Nigeria has necessitated the need for SMEs to find ways of generating new product features to satisfy customers [13]. Product development leads to increase in sale of existing products in unexplained markets. Diversification directs the organization towards introducing new products to new markets. Porter [14] shares the same view suggesting that high growth can best be achieved by identifying new markets for existing products or by developing new products or services for existing customers. Nooteboom [15] suggested that SMEs pursue product innovation strategies in emerging markets and marketing innovation strategies in mature niche markets in order to enhance their performance. Moore [28] also suggests that product development strategy is a very effective strategy in mature markets with products in late life cycle stages. Service positioning is employed as a market penetration strategy that ensure the growth of small and medium scale enterprises [29].
Yogo [18] in his study established a significant relationship between market penetration strategy and performance of SMEs. He explains that it leads to increase in sale of existing products in unexplained markets. SMEs compete in placing favorable price to their customer as a way of retaining their customers as well as attracting other potential customer through networking basing on pricing. Bauer and Colgan [30] argued that lower prices lead to higher demand and, therefore, to a large market. Though most of the managers perceive this is not good strategy for growth since customers may have perception that the product or service of low price is not standard one.

The quality of service strategy as explained by Yogo [18] implies that once managers of service businesses accurately understand what customers expect, the second critical challenge is to set service quality standards and goals for the organizations. The ability of an organization to succeed often rests with relatively with the quality of services rendered to customers [29]. A study by Iorun [31] indicated that market growth strategies such as creativity and risk taking significantly affect performance of SMEs. Uchegbulam et al., [32] in a study on growth strategies and performance of SMEs in Lagos, Nigeria showed significant relationship between product features and customer base; product customization and sales growth, value added products and revenue growth. It also indicated that better product quality has an influence on returns on investment. Pushpakumari and Toshimitsu [33] also identified product quality and customer service as the most crucial strategies in enhancing the performance of manufacturing SMEs in Japan and Sri Lanka.

\section{THEORETICAL FRAMEWORK}

This study adopted the business growth theory. The business growth theory was propounded by Penrose [34]. The theory offers strong principles governing the growth of firms and the rate at which firms can grow successfully. She claimed that there are a bundle of internal and external resources that help a firm to grow fast to realize competitive advantage. According to Penrose [34], firm size is incidental to the growth process, whereas firm growth is determined by the environmental factors. Penrose has also suggested that ignorance of these factors results in failure and loss of competitive advantage. The theory further shows that firms' resources were only meaningful in the context of its environment.

Firms are institutions that are created by people to serve different purposes and they operate in a disequilibrium thereby seeking to maintain administrative coordination within a multi stakeholder environment. Managers are motivated by the struggle for firm performance and growth hence the need for achievement and recognition to generate both creative innovations and adaptive responses through new 
Asenge, Emmanuel Lubem \& Asue, Timothy Terkimbir; Saudi J Bus Manag Stud, Jan., 2020; 5(1): 1-9

resource combinations [35]. Entrepreneurs and managers are also driven to create something novel and worthwhile and to work diligently to grow the firm into the next geographic territory or product market.

Though debates within the field of entrepreneurship and management have tended to focus on Penrose's contribution at a business-unit level of analysis and the notion of competitive advantage, some have argued that this emphasis on competitive advantage is a distortion of her true intent. Another critique is the testability of the theory that Penrose had developed. Unlike theoretical work today, that emphasizes constructs and relationships, Penrose mostly used case histories to develop some theoretical principals and logics, and she acknowledged that testing them remains problematic [36].

The business growth theory is relevant to this study because it provides key insights into how firms can grow fast and improve their performance [35]. For an individual entrepreneurial firm, growth is an evidence of the return of an entrepreneur's investment and self-fulfillment. Growth is also a condition of survival for young and small businesses as growing firms are found less vulnerable to failure than nongrowers. Managers in firms are posited to have purposive behavior in the pursuit of profitable growth, which allows for firm outcomes to be driven by multiple stakeholder interests and motivations. With a balanced focus on growth (as a natural drive of firms) and profitability (as a necessity for firm survival and continued growth), the theory offers a more holistic understanding of the process of firm growth and renewal that is both theoretically sound and practically grounded and provides key insights into how firms can create (sustainable) competitive advantage. With the adoption of this theory, managers of SMEs will be able to grow and expand fast.

\section{MATERIALS AND METHODS}

A survey research design was used in this study. The use of survey design enabled the researcher collect different opinions of owners on market growth strategies and performance of SMEs. The study covered SMEs in Makurdi Metropolis which is hub of commercial activities in Benue State. The population of this study is made up of 281 SMEs in Makurdi metropolis in four (4) sub-sectors as follows: Retail/Wholesale 92, Services 75, Agri-business 69 and Manufacturing 45. The target population includes owner-managers of selected SMEs in Makurdi metropolis. A census sampling method was used in this study since the population was small. A selfadministered questionnaire was used as the instrument of data collection. The questionnaire was designed on a four point Likert scale as follows: strongly agree (4), agreed (3), disagree (2) and strongly disagree (1). The questionnaire was distributed to the respondents through face-to-face distribution with the aid of two research assistants. Mean and standard deviation were used for data presentation and analysis while multiple linear regression was used to test formulated hypotheses at 0.05 significance level with the aid of the Statistical Package for Social Sciences (SPSS 21). The validity of instrument was established through content validity which was given to experts to ascertain whether the questionnaire items adequately measure the constructs. Factor analysis was used to measure construct validity of the instrument. Exploratory Factor Analysis (EFA) and Confirmatory Factor Analysis (CFA) were used for this purpose. The result of the Bartlett's test of Sphericity at $1 \%$ level of significance showed that the items were highly significant $(\mathrm{p}<0.001)$. The results of KMO and Bartlett's Test was .794 with Approx. Chisquare $=825.421$ and $\operatorname{sig}=.000$. The result is presented in Table 1:

\begin{tabular}{|lll|}
\hline \multicolumn{3}{|c|}{ Table-1: KMO and Bartlett's Test } \\
\hline Kaiser-Meyer-Olkin Measure of Sampling Adequacy. & .794 \\
\multirow{4}{*}{ Bartlett's Test of Sphericity } & Approx. Chi-Square & 852.421 \\
& Df & 10 \\
& Sig. & .000 \\
\hline \multicolumn{3}{|c|}{ Source: SPSS Data Output, 2019. } \\
\hline
\end{tabular}

The study conducted a pilot test in an attempt to test the reliability the research instrument. To test for reliability, the study used the internal consistency technique by employing the Cronbach Coefficient Alpha test. The result as presented in Table 2 shows that the Cronbach's Alpha for each of the constructs was greater than 0.70 . This implied that all the constructs were reliable and so were used in the study. It is asserted that a useful rule of thumb for research studies is that reliability should be at least 0.70 . 
Asenge, Emmanuel Lubem \& Asue, Timothy Terkimbir; Saudi J Bus Manag Stud, Jan., 2020; 5(1): 1-9

\begin{tabular}{|lc|}
\hline \multicolumn{2}{|c|}{ Table-2: Reliability Test Results } \\
\hline Variable & Cronbach's Alpha \\
\hline 1. Product Development Strategy & 0.717 \\
2. Market Penetration Strategy & 0.733 \\
3. Quality Customer Services Strategy & 0.708 \\
4. Performance of SMEs & 0.728 \\
Average Reliability & $\mathbf{0 . 7 2 2}$ \\
\hline Source: SPSS Data Output, 2019. \\
\hline
\end{tabular}

\section{Variable/Model Specification}

The study contains the dependent and independent variables. The independent variable (market growth strategies) comprises of product development strategy, market penetration strategy and quality customer service strategy. The dependent variable, performance of small and medium scale enterprises, is measured using sales growth and innovativeness. Performance of SMEs is regarded in this study as a function of Market Growth Strategies. The linear regression model is specified below:

PSMEs $=f($ MGRWS $)$

where;

PSMEs= Performance of SMEs (Dependent Variables) MGRWS = Market Growth Strategies (Independent Variable)

Given that market growth strategies comprise of three dimensions, the implicit form of the model is given as follows:
PSMEs $=\mathrm{f}(\mathrm{PDS}+\mathrm{MPS}+\mathrm{QCS})$

where:

PDS $=$ Product Development Strategy

MPS $=$ Market Penetration Strategy

QCS= Quality Customer Service Strategy

Thus, the explicit form of the model for the study will be as follows:

PSMEs $=\beta_{0}+\beta_{1}$ PDS $+\beta_{2}$ MPS $+\beta_{3}$ QCS $+\varepsilon$

where:

$\beta_{0}=$ intercept of the mode (Constant)

$\beta_{1}, \beta_{2}, \beta_{3}=$ regression coefficient

$\varepsilon=$ error term

\section{RESULTS AND DISCUSSION}

This section focuses on data presentation and analysis, test of hypotheses and discussion of findings.

\begin{tabular}{|c|c|c|c|c|c|}
\hline \multicolumn{6}{|c|}{ Table-3: Model Summary } \\
\hline Model & $\mathbf{R}$ & R Square & $\begin{array}{l}\text { Adjusted } \\
\text { R Square }\end{array}$ & $\begin{array}{l}\text { Std. Error of } \\
\text { the Estimate }\end{array}$ & $\begin{array}{l}\text { Durbin- } \\
\text { Watson }\end{array}$ \\
\hline 1 & $.774^{\mathrm{a}}$ & .529 & .521 & .609 & 1653 \\
\hline \multicolumn{6}{|c|}{$\begin{array}{l}\text { a. Predictors: (Constant), Quality customer service strategy, Market penetration strategy, } \\
\text { Product development strategy } \\
\text { b. Dependent Variable: Performance of SMEs }\end{array}$} \\
\hline
\end{tabular}

Source: Field Survey, 2019.

The result in Table 3 showed that the regression coefficient, $\mathrm{R}=.774$ indicates a positive relationship between the independent variables and dependent variable. The coefficient of determination
$\left(\mathrm{R}^{2}\right)$ was .529 and this implies that $52.9 \%$ of the variation in SMEs performance is explained by product development strategy, market penetration strategy and quality customer service strategy.

\begin{tabular}{|llllll|}
\hline \multicolumn{5}{c|}{ Table-4: Analysis of Variance (ANOVA) } \\
\hline Model & Sum of Squares & Df & Mean Square & F & Sig. \\
\hline Regression & 43.468 & 3 & 14.489 & 39.069 & $.000^{\mathrm{b}}$ \\
Residual & 88.639 & 277 & .371 & & \\
Total & 132.107 & 280 & & & \\
\hline a. & Dependent Variable: Performance of SMEs & & \\
b. & Predictors: (Constant), Quality customer & service & strategy, Market penetration strategy, \\
& Product development strategy
\end{tabular}

Source: Field Survey, 2019. 
The result of the analysis of variance as presented in Table 4 showed that the value of $F$ (39.069) is significant and the significance level (.000) which is less than 0.05 ( $\mathrm{P}$-value $=0.000<0.05)$. This implies that over all regression models is statistically significant, valid and fit. The valid regression model implies that all independent variables (product development strategy, market penetration strategy and quality customer service strategy) are capable of explaining the effect of growth strategies on performance of SMEs.

\begin{tabular}{|c|c|c|c|c|c|}
\hline \multicolumn{6}{|c|}{ Table-5: Coefficients of Variance } \\
\hline Model & & Std. Error & $\begin{array}{c}\text { Standardized } \\
\text { Coefficients } \\
\text { Beta }\end{array}$ & t & Sig. \\
\hline (Constant) & .811 & .426 & & 1.905 & .000 \\
\hline $\begin{array}{l}\text { Product devt. } \\
\text { Strategy }\end{array}$ & .386 & .118 & .252 & 3.266 & .001 \\
\hline $\begin{array}{l}\text { Market Penetration } \\
\text { Strategy }\end{array}$ & .708 & .106 & .474 & 6.720 & .000 \\
\hline $\begin{array}{l}\text { Quality Customer } \\
\text { Strategy }\end{array}$ & .510 & .071 & .436 & 7.223 & .000 \\
\hline
\end{tabular}

Source: `Field Survey, 2019.

The regression coefficient in Table 5 indicates that a unit increase in product development strategy would increase the performance of SMEs by $38.6 \%$, a unit increase in market penetration strategy would increase the performance of SMEs by $70.9 \%$ and a unit increase in quality customer service strategy would increase the performance of SMEs by $51.0 \%$. The result further shows that the market penetration strategy has more significant effect on the performance of SMEs in Makurdi metropolis, Benue State. The three hypotheses formulated in the study were thus rejected and alternate hypotheses accepted.

The result collected from the respondents showed that product development strategy has significant effect on the performance of SMEs in Makurdi metropolis, Benue State. The result of this study is in line with previous studies by Porter [14] whose findings showed a positive relationship between product development strategy and business performance. This result is agreed by Moore [28] who indicated that product development strategy significantly affect the market share of SMEs. Findings of the study also indicated a positive significant effect of market penetration strategy on the performance of SMEs in Makurdi metropolis, Benue State. This finding is in agreement with Adedamola [29] who found significant relationship between market penetration strategy and performance of small scale businesses. Similarly, Yogo [18] established that market penetration strategy leads to increase in sale of existing products in the market. Finally, result of the study indicated that there is positive significant effect of quality customer service strategy on the performance of SMEs in Makurdi metropolis, Benue State. The result corroborates previous studies by Porter [14]; Yogo [18] and Ifekwem and Adedamola [29] who all found significant relationship between customer service strategies and the performance of business organizations.

\section{CONCLUSION}

The study examined the effect of market growth strategies on the performance of small and medium scale enterprises in Benue State, Nigeria and findings revealed that market growth strategies have significantly affected the performance of SMEs in Benue State. The study concluded that product development strategy has significantly affected the performance of SMEs in Benue State. The study also concluded that market penetration strategy enable SMEs to expand their markets. Finally, the study concluded that quality customer service strategy has enhanced the performance of SMEs in Benue State. Based on findings of this study, it is expedient to recommend that owners of SMEs in Benue State should come-up with practical approaches in rebranding or repacking products according to the taste of the consumers to increase the customer base. Owners and managers of SMEs in Benue State should identify potential suppliers with quality products to ensure that large companies do not outshine them in the market. Also, owners of SMEs in Benue State should increase their customer base by creating awareness for products and services. The major limitation of study was its inability to include SMEs in other parts of Benue State. The study mainly focused on SMEs in Makurdi town. The growth strategies pursued by SMEs in other areas could be different as well as challenges they face. There is therefore need for further studies to cover other areas in Benue State and Nigeria at large. Further studies should cover more organizations across all sectors to provide a more broad based analysis. Other studies should consider other market growth strategies since the study was limited to product development strategy, 
market penetration strategy and quality customer service strategy.

\section{REFERENCES}

1. Anamekwe, C. (2001). Micro and Small-Scale Enterprises in Nigeria: Problems and Prospects. Being paper presented at Workshop on Grassroots Advocacy and Economic Development. September $11-13$.

2. Minniti, M. (2008). The role of government policy on entrepreneurial activity: productive, unproductive, or destructive? Entrepreneurship Theory and Practice, 32(5):779-790.

3. Arianoff, A. (2010). Role of SMEs in the Development of a Region. International Information Centre, 16 (5): 10-21.

4. Ajayi, O.A. (2002). Development of Small-Scale Enterprises in Nigeria. Being Paper Presented at Workshop on Grassroots Advocacy and Economic Development. September 11-13.

5. Mankins, M. C., \& Steele, R. (2005).Turning great strategy into great performance, Harvard Business Review (July-August), 64-72.

6. Kadiri, M., Ahmadian, R., Bockelmann-Evans, B., Rauen, W., \& Falconer, R. (2012). A review of the potential water quality impacts of tidal renewable energy systems. Renewable and sustainable energy reviews, 16(1), 329-341.

7. Johnson, G., \& Scholes, K. (2002).Exploring Corporate Strategy, $\left(6^{\text {th }}\right.$ edn $)$. Prentice Hall,

8. David, F. R. (2003). Strategic Management: Concepts and Cases (9th Edition). Pearson Education, Inc. Upper Saddle River, New Jersey.

9. Quinn, J. B., Mintzberg, H., \& James, R. M. (1988). The strategy process: concepts, contexts, and cases (p. 33). Englewood Cliffs, NJ: PrenticeHall.

10. McKelvie, A., \& Wiklund, J. (2010). Advancing firm growth research: a focus on growth mode instead of growth rate. Entrepreneurship Theory and Practice, 34(2):261-288.

11. Pearce, J. A., \& Robinson, R. B. (2007).Strategic Management: Formulation, Implementation and Control. Irwin, Boston.

12. Kiptugen, E. J. (2003). Strategic Responses to a Changing Competitive Environment. A Case Study of KCB, Unpublished MBA project, University of Nairobi.

13. Grant, R. M. (2008). Contemporary Strategy Analysis (Sixth). Blackwell Publishing.

14. Porter, M. E. (2006). Competitive Strategy: Techniques for Analyzing Industries and Competitors, New York: Free Press.

15. Nooteboom, B. (1994). Innovation and diffusion in small firms: Theory and evidence. Small Business Economics Journal 6 (5): 327-347.

16. Porter, M. E. (1998) Competitive Strategy. Technique for Analyzing Industries and Competitors. The Free Press.
17. Mascarenhas, K. S. (2006). Ethnic Minority Small and Medium-Sized Enterprise in England: Diversity and Challenges, paper presented to the 51st conference of the International Council for Small Business, Melbourne, Australia 18-21 June 2006.

18. Goto, K., Yogo, K., \& Higashii, T. (2013). A review of efficiency penalty in a coal-fired power plant with post-combustion $\mathrm{CO} 2$ capture. Applied Energy, 111, 710-720.

19. Ronge. E., Ndirangu. L. and Nyangito, H. (2002). Review of government policies for the promotion of Micro and small scale enterprises in Kenya. KIPPRA Discussion paper.

20. Ajide, F. M., Hameed, R. A., \& Oyetade, J. A. (2014). Environmental sustainability and financial performance of small and medium Enterprises (SMEs) in Nigeria: A study of selected firms in Lagos State. International Journal of Management Sciences and Humanities, 2(2), 39-55.

21. Wang, J. (2005). Carbon-nanotube based electrochemical biosensors: A review. Electroanalysis: An International Journal Devoted to Fundamental and Practical Aspects of Electroanalysis, 17(1), 7-14.

22. Aremu, M. A., \& Adeyemi, S. L. (2011). Small and medium scale enterprises as a survival strategy for employment generation in Nigeria. Journal of sustainable development, 4(1), 200.

23. Farouk, A., \& Saleh, M. (2011). An explanatory framework for the growth of Small and Medium Enterprises: A System Dynamics Approach. In International Conference of System Dynamics Society (Vol. 2011).

24. Raduan, C. R., Jegak, U., Haslinda, A., \& Alimin, I. I. (2009).Management, Strategic Management Theories and the Linkage with Organizational Competitive Advantage from the Resource Based Perspective European journal of Social Sciences. 2 (3): 123-131

25. Rumelt, D. (2002). Towards a Strategic Theory of the Firm.Alternative theories of the firm; Elgar Reference Collection.International Library of Critical Writings in Economics, 154 (2): 286-300.

26. Obasan Kehinde, A., \& Hassan Banjo, A. (2014). A test of the impact of leadership styles on employee performance: A study of department of petroleum resources. International Journal of Management Sciences, 2(3), 149-160.

27. Heimonen, T. (2012). What are the factors that affect innovation in growing SMEs?. European Journal of Innovation Management, 15(1), 122144.

28. Moore, R. (2004). Education and society: Issues and explanations in the sociology of education. Cambridge: Polity.

29. Ifekwem, N., \& Adedamola, O. (2016). Survival Strategies and Sustainability of Small and Medium Enterprises in the Oshodi-Isolo Local Government Area of Lagos State.ACTA University 
Asenge, Emmanuel Lubem \& Asue, Timothy Terkimbir; Saudi J Bus Manag Stud, Jan., 2020; 5(1): 1-9

SAPIENTIAE, Economics and Business Journal, 4(2):103-118

30. Bauer, C., \& Colgan, J. (2001). Planning for Electronic Commerce Strategy: an Explanatory Study from financial sector. Journal of Logistics Information Management, 14(1/2):24-32.

31. Iorun, J. I. (2014). Evaluation of survival strategies of Small and Medium Enterprises in Benue State, Nigeria.International Journal of Academic Research in Accounting, Finance and Management Sciences, 4(2): 255-263

32. Uchegbulam, P., Akinyele, S. and lbidunni, A. (2015).Competitive Strategy and Performance of Selected SMEs in Nigeria. International Conference on African Development Issues (ClJICA DI) 2015: Social and Economic Models for Development Track 326-333
33. Pushpakumari, M.D., \& Toshimitsu, W. (2015). Do Strategies Improve SME Performance? An Empirical Analysis of Japan and Sri LanKa.Meijo Asian Research Journal, 1(1):61-75

34. Penrose, E. T. (1959). The Theory of the Growth of the Firm. New York: Cambridge, MA

35. Kor, Y. Y., \& Mahoney, J.T. (2000). Penrose's resource-based approach: The process and product of research creativity. Journal of Managerial Studies, 37(1):109-139.

36. Echdar, H. S., \& Si, M., S. (2013). The Effects of Internal and External Environment on Human Capital Development. Empirical Study on Manufacturing Company. Gupublik, Indonesia. Journal of Business Management, 1(2):39-56.

\section{APPENDIX I}

\section{Regression}

\begin{tabular}{|c|c|c|c|c|c|c|c|}
\hline \multicolumn{8}{|c|}{ Variables Entered/Removed $^{\mathrm{a}}$} \\
\hline Model & \multicolumn{2}{|c|}{$\begin{array}{l}\text { Variables } \\
\text { Entered }\end{array}$} & \multicolumn{2}{|c|}{$\begin{array}{l}\text { Variables } \\
\text { Removed }\end{array}$} & \multicolumn{3}{|c|}{ Method } \\
\hline 1 & \multicolumn{2}{|c|}{$\begin{array}{l}\text { Quality customer } \\
\text { service strategy, } \\
\text { Market } \\
\text { penetration } \\
\text { strategy, Product } \\
\text { development } \\
\text { strategy }\end{array}$} & & & \multicolumn{3}{|l|}{ Enter } \\
\hline \multicolumn{8}{|c|}{ a. Dependent Variable: Performance of SMEs } \\
\hline \multicolumn{8}{|c|}{ b. All requested variables entered. } \\
\hline \multicolumn{8}{|c|}{ Model Summary $^{\mathbf{b}}$} \\
\hline Model & \multicolumn{3}{|c|}{ R Square } & \multicolumn{2}{|c|}{$\begin{array}{l}\text { Adjusted R } \\
\text { Square }\end{array}$} & $\begin{array}{l}\text { Std. Error of the } \\
\text { Estimate }\end{array}$ & Durbin-Watson \\
\hline 1 & $.774^{\mathrm{a}}$ & & 529 & & .521 & .609 & \\
\hline
\end{tabular}

a. Predictors: (Constant), Quality customer service strategy, Market penetration strategy, Product development strategy

b. Dependent Variable: Performance of SMEs

\begin{tabular}{|l|l|r|r|r|r|r|}
\hline \multicolumn{2}{|l|}{ ANOVA $^{\mathbf{a}}$} \\
\hline \multirow{2}{*}{ Model } & Sum of Squares & Df & Mean Square & F & Sig. \\
\hline \multirow{3}{*}{1} & Regression & 43.468 & 3 & 14.489 & 39.069 & $.000^{\mathrm{b}}$ \\
\cline { 2 - 8 } & Residual & 88.639 & 277 & .371 & & \\
\cline { 2 - 8 } & Total & 132.107 & 280 & & & \\
\hline
\end{tabular}

a. Dependent Variable: Performance of SMEs

b. Predictors: (Constant), Quality customer service strategy, Market penetration strategy, Product development strategy

\begin{tabular}{|c|c|c|c|c|c|c|}
\hline & & Coeff & nts $^{\mathrm{a}}$ & & & \\
\hline & & $\begin{array}{r}\text { Unst } \\
\text { Cos }\end{array}$ & $\begin{array}{l}\text { ardized } \\
\text { cients }\end{array}$ & $\begin{array}{l}\text { Standardized } \\
\text { Coefficients }\end{array}$ & $\mathrm{t}$ & Sig. \\
\hline & & $\mathrm{B}$ & Std. Error & Beta & & \\
\hline 1 & (Constant) & .811 & .426 & & 1.905 & .000 \\
\hline & Product development strategy & .386 & .118 & .252 & 3.266 & .001 \\
\hline & Market penetration strategy & .709 & .106 & .474 & 6.720 & .000 \\
\hline & $\begin{array}{l}\text { Quality customer service } \\
\text { strategy }\end{array}$ & .510 & .071 & .436 & 7.223 & .000 \\
\hline
\end{tabular}

